\title{
Oyunlaştırılmış Robot Etkinliklerinin Ortaokul Öğrencilerinin Problem Çözme ve Bilgi İşlemsel Düşünme Becerilerine Etkisi
}

\author{
Mahmure Kaya $^{1}$, Özgen Korkmaz*² ve Recep Çakır ${ }^{3}$
}

\section{Öz}

Anahtar Sözcükler

$\mathrm{Bu}$ araştırmanın amacı, oyunlaştırılmıș eğitsel robot etkinliklerinin, ortaokul öğrencilerinin problem çözmeye yönelik yansıtıcı düşünme becerilerine ve bilgi işlemsel düşünme beceri düzeylerine etkisini belirlemektir. Araştırmada öntest sontest kontrol gruplu yarı deneysel desen kullanılmıştır. Araştırmanın deney grubunu, 2018-2019 Eğitim-Öğretim Yılı'nda Bilişim Teknolojileri ve Yazılım Dersi 2. Dönem Destekleme ve Yetiştirme Kursuna kayıtlı 27 kişiden oluşan 6. sınıf öğrencileri oluşturmaktadır. Kontrol grubunu ise yine aynı kursta kayıtlı bulunan 24 öğrenci oluşturmaktadır. Araştırma verileri, Problem Çözmeye Yönelik Yansitıcı Düşünme Becerisi Ölçeği ve Bilgi Işslemsel Düşünme Beceri Düzeyleri Ölçeği (Ortaokullar için) kullanılarak toplanmıştır. Problem Çözmeye Yönelik Yansıtıcı Düşünme Becerisi Ölçeği beşli likert tipinde olup 14 maddedir. Ölçeğin iç tutarlık katsayısı $\alpha=0.83$ olarak hesaplanmıştır. Bilgi Işslemsel Düşünme Beceri Düzeyleri Ölçeği de beşli likert tipinde ve 22 maddedir. Ölçeğin iç tutarlık katsayısı $\alpha=0.81$ olarak hesaplanmıştır. Elde edilen veriler aritmetik ortalama, standart sapma, karma ANOVA kullanılarak analiz edilmiş ve şu sonuçlara erişilmiştir: Oyunlaştırılmış eğitsel robot etkinlikleri öğrencilerin problem çözmeye yönelik yansıtıcı düşünme becerilerine ve bilgi işlemsel düşünme beceri düzeylerine anlamlı bir katkı sağlamaktadır.

Oyunlaştırma

Eğitsel robotlar Bilgi işlemsel düşünme Problem çözme

Makale Hakkında

Gönderim Tarihi

08 Temmuz 2019

Kabul Tarihi

08 Temmuz 2020

Makale Türü

Araştırma Makalesi

DOI: $10.12984 /$ egeefd.588512

\section{The Effect of Gamified Robotics Activities on the Problem Solving and the Computational Thinking Skills of the Secondary School Students}

\section{Abstract}

The purpose of this study was to investigate the effect of gamified educational robotics activities on the reflective thinking skills towards problem solving and the computational thinking skills of the secondary school students. This study adopted a quasi-experimental research design. A total of 27 sixth grade students studying at a secondary school in Amasya during 2018-2019 academic year were recruited as the experimental group for this study in the scope of extra-curricular courses in Information Technologies and Software Course. The control group consisted of 24 sixth grade students. The data were obtained with Reflective Thinking Skill towards Problem Solving Scale and the Computational Thinking Scale. The Reflective Thinking Skill towards Problem Solving Scale is of the quintet likert type and consists of 14 items. The internal consistency coefficient of the scale was calculated as $\alpha=0.83$. The Computational Thinking Scale is also of the quintet likert type and consists of 22 items. The internal consistency coefficient of the scale was calculated as $\alpha=0.81$. The statistical data were analyzed via descriptive statistics and mixed ANOVA tests. The findings indicated that using the gamified robotics activities in coding education has significantly contributed to the development of the reflective thinking skills towards problem solving and the computational thinking skills of the students.
Keywords

Gamification Educational robots Computational thinking

Problem solving

Article Info

Received

July 08, 2019

Accepted

July 08, 2020

Article Type

Research Paper

Atıf: Kaya, M., Korkmaz, Ö. ve Çakır, R. (2020). Oyunlaştırılmış robot etkinliklerinin ortaokul öğrencilerinin problem çözme ve bilgi işlemsel düşünme becerilerine etkisi. Ege Eğitim Dergisi, 21(1), 54-70. doi:10.12984/egeefd.588512

\footnotetext{
* Sorumlu Yazar/Corresponding Author

1 (D) Milli Eğitim Bakanlığı, Amasya Ziyapaşa Ortaokulu Bilişim Teknolojileri ve Yazılım Öğretmeni, Türkiye, mahmurekaya@ gmail.com

2 (1) Amasya Üniversitesi, Teknoloji Fakültesi, Bilgisayar Mühendisliği, Türkiye, ozgenkorkmaz@ gmail.com

3 (D) Amasya Üniversitesi, Eğitim Fakültesi, Bilgisayar ve Öğretim Teknolojileri Eğitimi, Türkiye, recepcakir@gmail.com
} 


\section{Extended Abstract}

\section{Introduction}

Over the last decade, coding education for children has become widespread in Turkey as it has in many other countries. The purpose of early programming education is to allow children to acquire 21st century skills during the early periods of life (Yıldız Durak, Karaoğlan Yılmaz, Yılmaz, \& Seferoğlu, 2017). The basic 21st century skills that children are expected to gain can be listed as follows: Learning skills (the four C's), such as critical thinking, creativity, communication, and collaboration; Literacy Skills (IMT), such as information literacy, media literacy, and technology literacy; and Life Skills (FLIPS), such as flexibility, leadership, initiative, productivity, and social skills (Battle For Kids, 2019). Presumably regarded as one of the most important skills, basic coding skill, on the other hand, is considered as a significant part of logical reasoning and problem solving (European Commission, 2018).

Computational thinking skill that paves the way for the coding education is directly associated with the problemsolving skill. In this sense, it is argued that children with coding skills are able to easily detect the mistakes they make when compared to their peers, and so they can develop their problem-solving skills (Resnick \& Silverman, 2005). The work of Erdem (2018) tells us that coding education contributes to the problem solving and the computational skills of children. Armoni (2012) draws attention to the fact that there may be some difficulties in coding education for young children as they don't have enough abstracting skills or coding is not included in their interest area, on the other hand. Therefore, ready coding kits or educational robot kits developed by the students themselves have recently been in use. Thus, students can tangibly see the results of the programmes and codes they have produced (Çankaya, Durak, \& Yünkül, 2017).

Nowadays, such educational coding kits as Makey Makey, Tuşyarat and Tuşyap have frequently been employed in the robotics activities as they are more convenient for small kids. It is important to draw attention to the fact that applications that are used to design games mostly use screen-based game authoring platforms and the fact that more tangible interface designs such as Makey Makey are ignored. Lee, Kafai, Vasudevan and Davis (2014) conducted two workshops by using Makey Makey and scratch block-based coding programmes along with the secondary school students and concluded that including these kinds of educational coding kits add much to the learning process since they provide students with gamified learning environment. Gamification in education is to use funny elements of the games to integrate the attractiveness of playing games and the students into the learning process as well as to motivate them, by synthesizing them with a suitable and aesthetic design (Sezgin, Bozkurt, Y1lmaz, \& van der Linden, 2018). In this regard, this study has sought to investigate the effect of gamified educational robotics activities on the reflective thinking skills towards problem solving and the computational thinking skills of the secondary school students.

\section{Method}

This study adopted a quasi-experimental research design, pre-test and post-test with control group. A total of 27 sixth grade students studying at a secondary school in Amasya city during 2018-2019 academic year were recruited as the experimental group for this study in the scope of extra-curricular courses in Information Technologies and Software Course. The control group consisted of 24 sixth grade students. The control group is randomly selected. Before the experimental procedure, both groups were surveyed through pre-test measurement instruments, including the Reflective Thinking Skill towards Problem Solving Scale by Kızılkaya and Aşkar (2009) and the Computational Thinking Scale by Korkmaz, Çakır and Özden (2015). The former deals with the questioning, reasoning and evaluating factors in three subdimensions, whereas the latter delves into the creativity, algorithmic thinking, cooperative learning, critical thinking and problem-solving skills in five subdimensions. These instruments were also administered as the post-test survey instruments.

By using computers, both groups were instructed through demonstration method of teaching during five weeks in the Information Technologies and Software Course. The students conducted their activities as groups in doubles or threes as the number of the computers and the gamified robot kits were limited. Demir and Seferoğlu (2017) posit that group works are useful since they enable the learners to benefit from cooperative learning in Information Technologies and Software Course.

Those students who first completed the gamified activities in the experimental group were assigned with Scratch badges and their photos were taken to be exhibited on the ICT board for one week. Additionally, the group with the highest number of wins for five weeks were rewarded with the Teacher Special Award. Thus, the components, dynamics, and mechanics of the gamification activity were highlighted. Five different activities that aimed to gain students the same objectives with the experimental one were conducted in the control group. The 
difference with those in the experimental group was that no kit was used, and no game was included in the control group.

\section{Findings}

Based on the results of mixed ANOVA test, it was found that the reflective thinking skill towards problem solving scores of the participants in the experimental group showed statistically significant differences when compared to those in the control group. When the sub dimensions are examined, there are statistically significant differences in favor of questioning and evaluating subdimensions. When the means are examined, there is a significant difference between the scores in favor of the experimental group.

Following the comparison of the experiment and control groups, there is a statistically significant difference between the Computational Thinking Scale total scores of the participants. When the subdimensions are examined, the most significant difference exists in the thinking, followed respectively by creativity, cooperative learning, and critical thinking. When the means are examined, there is a significant difference between the scores in favor of the experimental group.

\section{Discussion and Conclusion}

This study has focused on the effect of gamified educational robotics activities on the reflective thinking skills towards problem solving and computational thinking skills of the secondary school students. Based on the results derived from the statistical data, it has been concluded that coding education through gamified robotics activities has significantly contributed to the development of reflective thinking skills towards problem solving of the students. Similarly, it has been revealed that the computational thinking skills of the students has developed through the gamified robotics activities in coding education.

It has also been found that the activities conducted in the control group had a limited contribution on the reflective thinking skills towards problem solving of the students, but a significant contribution on the computational thinking skills of the students. As an explanation for this, it can be noted that the students show great interests in block-based coding courses whether gamified robotics activities are included or not. This is because block-based coding environments are easier and have clearer interfaces when compared to the textbased ones (Aytekin, Sönmez Çakır, Yücel, \& Kulaözü, 2018). 


\section{Giriş}

Günümüzde çocuklara yönelik kodlama eğitimi dünyada olduğu gibi Türkiye'de de dikkat çeken bir konu durumuna gelmiştir. Çocuklara erken yaşta verilen kodlama eğitimindeki amaç, mümkün olduğu kadar küçük yaşta 21. yüzyıl becerilerini kazandırmaya çalışmaktır (Yıldız Durak, Karaoğlan Yılmaz, Yılmaz ve Seferoğlu, 2017). Günümüz öğrencilerinin sahip olması beklenen 21. yüzyıl becerileri (P21) arasında; eleştirel düşünme, yaratıcılık, iletişim, iş birliği, problem çözme gibi öğrenme ve yenilenmeye dair beceriler; esneklik, girişimcilik, üretkenlik, uyum gibi yaşam ve meslek becerileri; bilgi ve iletişim teknolojileri okuryazarlığı, medya okuryazarlığı gibi medya ve teknoloji becerileri yer almaktadır (Battle For Kids, 2019). Mantıksal akıl yürütme ve problem çözmenin bir parçası olarak görülen kodlama becerisi ise 21. yüzyıl becerilerinin belki de en önemlilerinden biridir (European Commission, 2018).

Çocuklara verilen kodlama eğitiminin özellikle bilgi işlemsel düşünme, yaratıcılık ve problem çözmede başarı kazandırdığını fark eden birçok ülke, ilkokuldan hatta anasınıfından itibaren müfredatlarına kodlama eğitimini koymaya başlamıştır (Baz, 2018). ISTE (International Society for Technology in Education)'ye (2019) göre bilgi işlemsel düşünme bir çeşit analitik düşünce şekli olup, bilgisayarların işlem yetenekleri ile insanların zekâsını birleştirmektir. Özden’e (2015) göre bilgi işlemsel düşünme, herhangi bir konuda karşılaştığımız bir problemin çözümünde, bilgisayarı üretime dönük bir araç olarak kullanmamızı sağlayan bilgi beceri ve tutumlara sahip olma düzeyimizdir. Bilgi işlemsel düşünmenin amacı sadece öğrencileri bilgisayar bilimlerinde uzman yapmak değil, aynı zamanda öğrencilerin bilgi işlemsel düşünme becerilerini diğer derslerde ya da hayatın diğer alanlarında karşılaştıkları problemlerde uygulamalarını sağlamaktır (Barr, Harrison ve Conery, 2011). Bu bağlamda bilgi işlemsel düşünme becerisi sadece mesleği ya da ilgi alanı bilgisayar olanların değil, günümüzde tüm bireylerin sahip olması gerektiği düşünülen bir beceridir (Korkmaz, Çakır, Özden, Oluk ve Sarığlu, 2015). Erken yaşta çocuklara verilen kodlama eğitimlerinin amaçlarından birisinin de söz konusu bu becerilerin kazandırılması yönünde olduğu söylenebilir.

Kodlama eğitiminin de temelini oluşturan bilgi işlemsel düşünme olgusu, aslında problem çözme yeteneği ile doğrudan ilişkilidir. Kodlama eğitimi sayesinde herhangi bir konuda problem çözmeye çalışan çocukların yaptıkları hataları daha net ve hızlı görebildikleri ve bu sayede süreci ve sonucunu değerlendirme kabiliyetlerinin arttığı ifade edilmektedir (Resnick ve Silverman, 2005). Kodlama ile çocuklar; yaratıcı düşünmeyi, iş birlikli yaklaşımla çalışmayı, problemleri farklı açılardan ele almayı ve farklı çözüm yolları üretebilmeyi öğrenirler (Yıldız Durak ve diğ. 2017). Kızılkaya ve Aşkar (2009) tarafindan yapılan bir araştırmada, problem çözmeye yönelik yansıtıcı düşünme becerileri aşamalarının sorgulama, değerlendirme ve nedenleme olduğu belirtilmiştir. Günlük hayatta veya kodlama yaparken herhangi bir problemi çözen çocukların da önce durumu ve problemi sorguladıkları, çözüm sürecinde geriye dönüp bakarak durum değerlendirmesi yaptıkları ve en son neden-sonuç ilişkisini kurdukları bir süreci izlemekte oldukları söylenebilir. Erdem (2018) yaptığı çalışmada, kodlama eğitiminin, öğrencilerin problem çözme ve bilgi işlemsel düşünme becerilerini geliştirdiği yönünde bulgular elde etmiştir.

Yapılan bilimsel çalışmalardan hareketle, kodlamanın her yaştan öğrencinin problem çözme ve bilgi işlemsel düşünme becerisinin gelişimine katk1 yapacağı söylenebilir. Çetin (2012) yaptığı çalışmada, küçük yaştaki öğrencilerin programlama eğitimi sayesinde, problem çözme becerilerinin arttığını kaydetmiştir. Ayrıca öğrenciler erken yaşta aldıkları kodlama eğitimi ile kazanacakları bilgi işlemsel düşünme becerileri sayesinde hem bilgisayar ortamında hem de gerçek hayatta karşılaştıkları problemlerin üstesinden gelmeyi başaracaklardır (Barr ve Stephenson, 2011). Ancak öğrencilere sadece öğrenme ortamını sağlamak, etkili bir öğretim için yeterli olmayacaktır (Kalelioğlu ve Gülbahar, 2014). Aslında günümüzde çocuklara yönelik olarak geliştirilen kodlama yazılımları, karmaşık kod yapılarından arındırılmış ve küçük çocukların motivasyonlarını artırmaya yönelik olarak eğlenceli uygulamalar yapabilecekleri şekilde tasarlanmıştır (Baz, 2018). Buna rağmen, küçük yaş gruplarında soyutlama becerilerinin yeterli olmaması ve kodlamanın her zaman çocukların ilgi alanlarına hitap etmemesi nedeniyle kodlama eğitiminde bazı zorluklar yaşanmaktadır (Armoni, 2012). Bu yüzden de kodlama eğitiminde son yıllarda hazır kitler veya öğrencilerin kendi geliştirdikleri eğitsel robot kitleri kullanılmaya başlanmıştır. Böylece öğrenciler ürettikleri kodların ve programların sonuçlarını somut olarak görebilmektedirler (Çankaya, Durak ve Yünkül, 2017).

Eğitsel robotlar ile çalışan öğrencilerin ellerinde somut nesnelerin olması ve anında dönüt verebilmeleri onlarda gerçek yaşam problemleri ile ilgilendikleri hissini doğurmakta, bu da motivasyonlarını arttırmaktadır (Üçgül, 2017). Küçük ve Şişman'ın (2016) öğreticiler ile yaptıkları araştırmalar sonucunda öğreticiler, robotik kodlama eğitiminin öğrencilere oyun ve eğlence ortamı sunduğunu, böylece daha kolay öğrendiklerini belirtmişlerdir. Kodlama eğitimini somutlaştırarak vermeyi amaçlayan eğitsel robotlar, robotik kitleri ve setler son yıllarda bir hayli yaygınlaşmış durumdadır (Numanoğlu ve Keser, 2017). Yapılan çalışmalar incelendiğinde eğitimde en çok kullanılan setlerin Lego Mindstorms robot setleri, mBot-STEM Educational robot kiti ve Arduino robot kitleri olduğu söylenebilir (Oluk ve Korkmaz, 2018). Ancak son dönemlerde özellikle ilkokul ve ortaokul öğrencileri 
için Makey Makey, Tuşyarat, Tuşyap gibi eğitsel hazır robot kitlerinin küçük yaş gruplarının seviyeleri için daha uygun olmasından dolayı, robotik eğitim uygulamalarında yaygın olarak kullanıldığı söylenebilir. Lee, Kafai, Vasudevan ve Davis (2014), oyun yapmak için kullanılan uygulamaların çoğunun ekran tabanlı tasarıma odaklandığına ve Makey Makey gibi elle tutulur arayüz tasarımlarının göz ardı edildiğine dikkat çekerek ortaokul öğrencileri ile Makey Makey ve Scratch (blok kodlama programı) kullanarak iki adet atölye çalışması gerçekleştirmiş̧ler ve sonuçta bu tür eğitsel robot kitlerinin sürece dahil edilmesinin, oyunlaştırılmış bir öğrenme ortamı sağlamasından dolayı süreci pozitif etkilediğini belirtmişlerdir.

Oyunlaştırma, en yaygın ve kabul görmüş tanımıyla oyun tasarım ögelerinin, oyun dışındaki yaşantılarda kullanılmasıdır (Deterding, Sicart, Nacke, O'Hara ve Dixon, 2011). Werbach ve Hunter (2012) oyunlaştırmayı, önce bir oyunu neyin başarılı, çekici kıldığını anladıktan sonra, oyunların neden bu kadar büyük bir güce sahip olduğunu ve oyunların neler yapabileceğini keşfetmek sonra da bu tekniklerin bazılarını alıp, uygun şekilde başka durumlara uygulamak olarak tanımlamış̧ır. Yani temelde oyunlaştırmanın ana fikri, oyunsal olmayan bağlamlar, hizmet, ürün veya uygulamalarda oyun tasarım sürecinden yararlanarak ve bu tasarım sürecinin elementlerini kullanarak istenen davranışları motive etmektir (Sezgin, Bozkurt, Yılmaz ve van der Linden, 2018).

Eğitimde oyunlaştırma ise oyunun özünde var olan eğlenceli ögeleri, uygun bir tasarım ve estetik bir yaklaşımla sentezleyerek oyun oynamanın cazibesini, öğrencileri öğrenme sürecine dahil etmek ve onları daha uzun süre motive etmek amacıyla kullanmaktır (Sezgin ve diğ., 2018). Oyunlaştırma tasarımında Werbach ve Hunter (2012) üç basamaktan oluşan, yukarıdan aşağıya doğru dinamikler, mekanizmalar ve bileşenler olarak konumlanmış, piramit şeklinde bir oyunlaştırma modeli geliştirmiştir. Dinamikler; kısıtlamalar, duygular, ilerleme, hikâyeleştirme gibi oyunlaş̧ırma tasarımının en temel prensipleridir. Mekanikler; ödüller, iş birliği ve yarışma, geri bildirim, meydan okuma, şans faktörü gibi daha somut basamaklardır. Bileşenler ise oyunlaştırma sürecinin en belirgin ve ilk akla gelen ögeleri olup avatar, puan, rozet, lider cetveli, hediye verme gibi enstrümanlardan oluşmaktadır.

Bir eğitimi veya öğretim durumunu oyunlaştırırken tüm unsurları bu oyun tasarımında kullanmaya gerek yoktur. Temel amaç öğrenenleri motive etmek, bunu uzun süre yapmak ve motivasyon sonucunda ortaya çıkan davranışlardır (Bozkurt ve Genç Kumtepe, 2014). Arkün Kocadere ve Samur (2016) oyunlaştırmanın, eğitsel oyun tasarlamaktan daha kolay ve maliyetinin düşük olduğunu ancak oyunlaştırma tasarımında göz ardı edilmemesi gereken en önemli noktalardan birisinin eğlenceden uzaklaşmamak olduğunu vurgulamışlardır. Oyunlaştırmanın bir yöntem değil, öğrenmeyi daha ilginç kılmayı amaçlayan bir tasarım ve uygulamalar bütünü olduğu söylenebilir. Oyunlaştırma tasarımını başarısız yapan en önemli sebeplerden biri ise içsel ve dışsal motivasyon dengesini iyi kuramamaktır. Sadece dışsal motivasyon kaynaklı bir oyunlaştırma uygulaması kısa vadede çalışsa da uzun vadede genellikle başarısızlıkla sonuçlanır (Yılmaz, 2015). Oyunlaştırmanın amacına ulaşabilmesi için öğrencilerin içsel motivasyonlarının dışsal motivasyonlarına göre daha fazla artması beklenmektedir (Gökkaya, 2014). Sarı ve Altun (2016) tarafindan yapılan çalışmada, oyunlaştırma yönteminin öğrencilerin derse gösterdikleri ilgi ve motivasyon üzerindeki etkileri araştıılmış ve çalışmanın sonucunda deney grubunun, kontrol grubuna göre motivasyon ve ilgisinin daha yüksek olduğu tespit edilmiştir. Küçük ve Şişman'ın (2016) yaptığı çalışmada ise robotik eğitim süreci, bir oyun senaryosu eşliğinde öğrencilere sunulmuş, sonuçta öğreticilerin büyük bir kısmı oyunlaştırmanın süreci daha eğlenceli hâle getirdiğini ve öğrencilerin derse ilgi ve motivasyonlarının arttığını belirtmişlerdir. Ayrıca, Sarı ve Altun (2016) yaptıkları çalışmada, oyunlaştırma sürecinin öğrenciler arasında bir rekabet ortamı oluşturduğunu ve bunun öğrenciler üzerinde pozitif etkiler göstererek öğrencilerin motivasyonunu arttırdığını belirtmişlerdir.

Alanyazında eğitsel robot etkinlikleri ile bilgi işlemsel düşünme ya da problem çözme arasındaki etkiyi inceleyen çalışmalara rastlamak mümkündür. Ancak oyunlaştırılmış eğitsel robot etkinlikleri ile öğrencilerin problem çözmeye yönelik yansıtıcı düşünme becerileri ve bilgi işlemsel düşünme beceri düzeylerini aynı anda inceleyen bir çalışmaya rastlanmamıştır. Alanyazında robot setler veya Scratch, Mblock gibi blok kodlama yazılımların birlikte kullanımı ile ilgili çok sayıda çalışma olmasına rağmen (Kasalak, 2017; Korkmaz, 2016; Küçük ve Şişman, 2016; Numanoğlu ve Keser, 2017; Strawhacker ve Bers, 2015), bunlara oyunlaştırma dinamiklerini de ekleyerek inceleyen çalışmalarla karşılaşılmadığı için, bu çalışma, alana katkı sağlayabilir. Nitekim çalışmada, oyunlaştırma sürecinin öğrenciler arasında bir rekabet ortamı oluşturacağ 1 ve bu durumun öğrencilere olumlu katkılarda bulunabileceği düşünülmektedir. Çalışma, alanyazında, eğitsel robotların oyunlaştırmayla birleştirilerek kullanımına dönük bir örnek de olabilir. Bu bağlamda çalışmada, oyunlaştırılmış eğitsel robot etkinliklerinin, ortaokul öğrencilerinin problem çözmeye yönelik yansıtıcı düşünme becerilerine ve bilgi işlemsel düşünme beceri düzeylerine etkisinin olup olmadığının tespit edilmesi amaçlanmıştır. 


\section{Problem Cümlesi ve Alt Problemler}

Oyunlaştırılmış eğitsel robot etkinliklerinin, ortaokul öğrencilerinin problem çözmeye yönelik yansıtıcı düşünme becerilerine ve bilgi işlemsel düşünme beceri düzeylerine etkisi var mıdır?

1. Öğrencilerin problem çözmeye yönelik yansıtıcı düşünme beceri puanlarına ilişkin tekrarlı ölçümlerinde gruplar arasında anlamlı bir farklılık var mıdır?

2. Öğrencilerin bilgi işlemsel düşünme becerileri puanlarına ilişkin tekrarlı ölçümlerinde gruplar arasında anlamlı bir farklılık var midır?

\section{Yöntem}

\section{Araştırmanın Deseni}

$\mathrm{Bu}$ araştırma öntest, sontest kontrol gruplu yarı deneysel araştırma deseni ile yürütülmüştür. Araştırmanın bağımlı değişkenleri öğrencilerin problem çözmeye yönelik yansıtıcı düşünme becerileri ve bilgi işlemsel düşünme beceri düzeyleridir. Araştırmanın bağımsız değişkeni ise deney grubuna uygulanan oyunlaştırılmış eğitsel robot etkinlikleridir.

\section{Çalışma Grubu}

Araştırmanın deney grubunu 2018-2019 Eğitim-Öğretim Yılı’nda Amasya'da bir ortaokulun 6. sınıfında öğrenim gören, Bilişim Teknolojileri ve Yazılım Dersi 2. Dönem Destekleme ve Yetiştirme Kursu'na kayıtlı 27 öğrenci oluşturmaktadır. Kontrol grubunu ise yine aynı okul ve sınıf düzeyinde öğrenim gören 24 öğrenci oluşturmaktadır. Tablo 1'de öğrencilerin grup ve cinsiyetlerine göre dağılımı özetlenmiştir.

Tablo 1

Ögrencilerin Grup ve Cinsiyetlerine Göre Dă̆ılımı

\begin{tabular}{lccc}
\hline Grup & Erkek & K1z & Toplam \\
\hline Deney grubu & 13 & 14 & 27 \\
Kontrol grubu & 10 & 14 & 24 \\
Toplam & 23 & 28 & 51 \\
\hline
\end{tabular}

\section{Veri Toplama Araçları}

Araştırmanın verilerinin toplanması için Problem Çözmeye Yönelik Yansıtıcı Düşünme Becerisi Ölçeği ve Bilgi İşlemsel Düşünme Beceri Düzeyleri Ölçeği (Ortaokullar için) kullanılmıştır.

Problem Çözmeye Yönelik Yansıtıcı Düşünme Becerisi Ölçeği. Ölçek, Kızılkaya ve Aşkar (2009) tarafından geliştirilmiştir. Ölçekte ele alınan boyutlar, problem çözerken yansıtıcı düşünme sürecinde gerçekleştirilen eylemlerin üç ana noktası göz önünde bulundurularak ortaya konulmuştur. Bunlar; sorgulama, nedenleme ve değerlendirmedir. Bu bağlamda ölçeğin 5 maddesi sorgulama, 4 maddesi nedenleme ve 5 maddesi değerlendirme faktöründe bulunmaktadır. Ölçek, beşli likert tipinde ve 14 maddeden oluşmaktadır. Ölçeğin toplam puanı, tüm maddelere verilen cevapların toplanmasıyla hesaplanmaktadır. Toplam puan yükseldikçe yansıtıcı düşünme becerisine sahip olma düzeyi yükselir. Faktörlerin güvenilirlik kanıtları için iç tutarlılık katsayısı hesaplanmıştır. Analiz sonucunda iç tutarlılık katsayısı; nedenleme faktörü için $\alpha=0.71$, sorgulama faktörü için $\alpha=0.73$, değerlendirme faktörü için $\alpha=0.69$ 'dur. Ölçeğin tümü için iç tutarlılık katsayısı ise $\alpha=0.83$ hesaplanmıştır.

Bilgi İşlemsel Düşünme Beceri Düzeyleri Ölçeği (Ortaokullar için). Ölçek, Korkmaz, Çakır ve Özden (2015) tarafından geliştirilmiş ve ortaokul seviyesine uyarlanmıştır. Ölçeğin 5 alt faktörü bulunmaktadır. Bunlar; yaratıcılık, algoritmik düşünme, iş birlikli öğrenme, eleştirel düşünme ve problem çözme faktörleridir. Yaratıcılık faktöründe 4, algoritmik düşünme faktöründe 4, iş birlikli öğrenme faktöründe 4, eleştirel düşünme faktöründe 4 ve problem çözme faktöründe de 6 madde yer almaktadır. Ölçekte, problem çözme faktöründeki bu 6 madde ters maddeler olarak yer almaktadır. Ölçek, beşli likert tipinde cevaplanan toplam 22 sorudan oluşmaktadır. Faktörlerin iç tutarlık katsayıları yaratıcılık için $\alpha=0.84$, algoritmik düşünme için $\alpha=0.87$, iş birlikli öğrenme için $\alpha=0.87$, eleştirel düşünme için $\alpha=0.78$ ve problem çözme için $\alpha=0.73$ olarak hesaplanmıştır. Ölçeğin tümü için iç tutarlılık katsayısı $\alpha=0.81$ 'dir. 


\section{Veri Toplama Süreci}

Deneysel İşlemler. Araştırmada her iki gruba da deneysel işlemden önce öntest uygulanmıştır. Öntest olarak her iki gruba da Problem Çözmeye Yönelik Yansıtıcı Düşünme Becerisi Ölçeği ve Bilgi Işslemsel Düşünme Beceri Düzeyleri Ölçeği uygulanmıştır. Ayrıca, araştırmada uygulanan testlerin aynısı, deneysel işlemin sonunda her iki gruba sontest olarak uygulanmıştır. Her iki gruba da gösterip-yaptırma yöntemi uygulanmış olup her iki grup da dersleri Bilişim Teknolojileri ve Yazılım Sınıfı'nda bilgisayar başında uygulama yaparak işlemişlerdir. Her iki grupta da öğrenciler oyunlaştırılmış robot kitlerinin sayısının ve bilgisayar sayılarının yetersiz olmasından dolayı ikişerli veya üçerli grup çalışması yapmışlardır. Bilişim Teknolojileri ve Yazılım Dersi’nde grup çalışması yapılması öğrencilerin iş birlikli öğrenme yönteminden yararlanmalarına olanak sağladığı için, zaman zaman pozitif bir durum olarak görülmektedir (Demir ve Seferoğlu, 2017).

Deney Grubu. Araştırmada deney grubuna beş hafta süre ile oyunlaştırılmış eğitsel robotlar yardımıyla blok kodlama programı olan Scratch öğretilmeye çalışılmıştır. Yapılan etkinliklerde oyunlaştırılmış eğitsel robot kitlerinden yararlanılmıştır. Bunlar Tuşyarat, Tuşyap ve Makey Makey kitleridir. Bu kitlerin sayısı toplamda dokuz adet olduğu için deney grubu üçer kişilik gruplara bölünmüştür. Deney grubunda yapılan her bir etkinlik için iki ders saati süresi kadar süre belirlenmiş ve etkinliklerin ders planları hazırlanmış olup örnek bir etkinlik planı Ek A'da sunulmuştur. Deney grubunda beş hafta için toplam beş adet etkinlik uygulanmıştır. Bunlar:

1. Etkinlik: Kesilince bağıran meyve ve sebzeler. Bu etkinlikte amaç, öğrencinin blok tabanlı programlama aracının ara yüzünü ve özelliklerini tanıması ve sahneye karakter ekleyerek basit bir program yapabilmesidir. Scratch programında oyunun kodlaması yapıldıktan sonra Tuşyarat (Tuşyap ya da Makey Makey) kitine bağlanarak oynanır.

2. Etkinlik: Meyvelerden piyano oyunu. Bu etkinlikte amaç, öğrencilerin, verilen bir problemin çözümü için bir algoritma geliştirmeleri ve istenilen programı blok tabanlı kodlama aracında verilen ölçütlere göre geliştirerek düzenlemeleridir.

3. Etkinlik: Tel оуипи. Bu etkinlikte amaç, öğrencilerin algılama bloklarını ve doğrusal mantık yapısını içeren programları öğrenmeleridir.

4. Etkinlik: Zıplayan balerin oyunu. Bu etkinlikte amaç, öğrencilerin sabit ve değişken kavramlarını öğrenmelerini ve bunları problemlerin çözümünde kullanmalarıdır.

5. Etkinlik (Havuç ezme oyunu). Bu etkinlikte amaç, öğrencilerin çoklu karar yapısını ve döngüleri içeren programları oluşturabilmeleridir.

Oyunların tümünde oyunu ilk yapan grubun üyelerine Scratch rozetleri takılarak fotoğrafları çekilmiş ve bu fotoğraflar bir hafta boyunca bilişim panosunda sergilenmiştir. Ayrıca 5 hafta boyunca en çok birincilik elde eden grup, öğretmen özel ödülünün sahibi olmuştur. Böylece oyunlaştırma uygulamasının bileşenleri, dinamikleri ve mekanikleri somutlaştırılmıştır. Scratch rozetleri ile oyunlaştırma mekaniklerinden rekabet ve meydan okuma ögelerine; birincilerin bilişim panosunda sergilenmesi ile oyunlaştırma bileşenlerinden hediye verme ve ödül ögelerine, verilen ögretmen özel ödülü ile ise oyunlaştırmanın bileşenlerinden liderlik ve rol paylaşımı ögelerine vurgu yapılmıştır.

Kontrol Grubu. Kontrol grubuna ise oyunlaştırılmış eğitsel robotlar olmadan kodlama (Scratch) eğitimi verilmiştir. Öğrenciler Bilişim Teknolojileri ve Yazılım Sınıfı'ndaki bilgisayarların sayısının yetmemesi sebebi ile yine ikişerli gruplar halinde ders işlemişlerdir. Her bir etkinlik için iki ders saati süresi kadar süre belirlenmiştir. Öğrencilere aynı kazanımları vermeyi amaçlayan beş farklı uygulama yapılmıştır. Bu uygulamaların deney grubundakilerden farkı herhangi bir eğitsel robot kullanılmamış olması ve herhangi bir oyunlaştırma uygulaması yapılmamış olmasıdır. Kontrol grubunda yapılan uygulamalar ve amaçları aşağıda görülmektedir:

1. Etkinlik: Kediyi yürütelim. Bu etkinlikte amaç, öğrencinin blok tabanlı programlama aracının ara yüzünü ve özelliklerini tanıması ve sahneye karakter ekleyerek basit bir program yapabilmesidir.

2. Etkinlik: Interaktif kalem. Amaç, öğrencilerin verilen bir problemin çözümü için bir algoritma geliştirmeleri ve verilen bir kod parçasını belirlenen ölçütlere göre blok tabanlı programlama ortamını kullanarak geliştirerek düzenlemeleridir.

3. Etkinlik: Hareketli labirent uygulaması. Amaç, öğrencilerin algılama bloklarını ve doğrusal mantık yapısını içeren programları öğrenmeleridir.

4. Etkinlik: İki sayının toplamını bulan program. Amaç, öğrencilerin sabit ve değişken kavramlarını öğrenmeleri ve bunları problemlerin çözümünde kullanmalarıdır. 
5. Etkinlik: Akvaryum оуипu. Amaç, öğrencilerin çoklu karar yapısını ve döngüleri içeren programları oluşturabilmeleridir.

\section{Veri Analizi}

Araştırma sürecinde toplanan veriler üzerinde yapılacak olan analiz türüne karar vermek amacı ile normallik testi yapılmıştır. Tablo 2'de verilerin Shapiro-Wilk testine göre normal dağılıma sahip olup olmadığını gösteren bilgiler özetlenmiştir.

Tablo 2

Normallik Testi

\begin{tabular}{|c|c|c|c|c|c|c|c|c|}
\hline & \multirow[b]{2}{*}{ Uygulama } & \multirow[b]{2}{*}{ Grup } & \multicolumn{3}{|c|}{ Kolmogorov-Smirnov ${ }^{a}$} & \multicolumn{3}{|c|}{ Shapiro-Wilk } \\
\hline & & & $\begin{array}{c}\text { Test } \\
\text { İstatistiği }\end{array}$ & $s d$ & $p$ & $\begin{array}{c}\text { Test } \\
\text { İstatistiği }\end{array}$ & $s d$ & $p$ \\
\hline \multirow{4}{*}{$\begin{array}{l}\text { Problem Çözmeye } \\
\text { Yönelik Yansitıci } \\
\text { Düşünme Becerisi } \\
\text { Ölçeği }\end{array}$} & \multirow{2}{*}{ Öntest } & Deney & 0.09 & 27 & $.200^{*}$ & 0.98 & 27 & .757 \\
\hline & & Kontrol & 0.09 & 24 & $.200^{*}$ & 0.95 & 24 & .300 \\
\hline & \multirow{2}{*}{ Sontest } & Deney & 0.12 & 27 & .200 & 0.94 & 27 & .157 \\
\hline & & Kontrol & 0.17 & 24 & .062 & 0.95 & 24 & .211 \\
\hline \multirow{4}{*}{$\begin{array}{l}\text { Bilgi İşlemsel Düşünme } \\
\text { Beceri Düzeyleri Ölçeği }\end{array}$} & \multirow{2}{*}{ Öntest } & Deney & 0.11 & 27 & $.200^{*}$ & 0.94 & 27 & .157 \\
\hline & & Kontrol & 0.20 & 24 & .018 & 0.90 & 24 & .020 \\
\hline & \multirow{2}{*}{ Sontest } & Deney & 0.09 & 27 & $.200^{*}$ & 0.97 & 27 & .711 \\
\hline & & Kontrol & 0.11 & 24 & $.200^{*}$ & 0.95 & 24 & .214 \\
\hline
\end{tabular}

Gruplardaki öğrenci sayısının 35'den küçük olması durumunda Shapiro-Wilk testi (McKillup, 2012; Shapiro ve Wilk, 1965) kullanılmaktadır. Araştırma kapsamında gruplardaki öğrenci sayısı 35'den az olduğu için normallik testinde Shapiro-Wilk'e göre değerlendirme yapılmıştır. Tablo 2'de görüldüğü gibi, Kontrol grubu Bilgi Işslemsel Düşünme Beceri Düzeyleri Ölçeği öntesti dışında, deney ve kontrol gruplarının hem öntest hem de sontest puanlarının normal dağılıma sahip oldukları görülmüştür $(p>.05)$. Kontrol grubu Bilgi Işslemsel Düşünme Beceri Düzeyleri Ölçeği öntesti değerinin .018 olması $(p<.05)$ sebebi ile çarpıklık değerlerine bakılmış ve -1.5 ile +1.5 aralığında olduğu için parametrik analiz yapılmasına karar verilmiştir (Büyüköztürk, 2013). Bu farklılıkların gruplar arası ve gruplar içinde anlamlı olup olmadığını test etmek ve araştırmanın istatistiksel tutarlığı ve sağlamlığı açısından deneysel sürecin etkililiğini belirlemek için karma ANOVA analizinin yapılması tercih edilmiştir. $\mathrm{Bu}$ analizi gerçekleştirmeden normal dağılım kovaryanslarının eşitliği ve varyansların eşitliği varsayımları test edilmiş karma ANOVA'nın normallik varsayımlarının karşılandığı tespit edilmiştir. Yapılan analizlerde Box's Test of Equality of Covariance Matrices tablosu $p$ değeri .05'den büyük çıktığı için kovaryans matrislerinin eşitliği varsayımı sağlanmıştır. Benzer şekilde Levene F testi $(p>.05)$ sonucunda da varyansların homojen olduğu varsayımı karşılanmıştır.

\section{Etik Konular}

$\mathrm{Bu}$ araştırmanın yürütülebilmesi için Amasya Valiliğinin 31.10.2019 tarih ve E.21436207 sayılı yazısıyla oluru ve Amasya İl Milli Eğitim Müdürlüğünün 06.11.2019 tarih ve E.21844571 sayılı yazısıyla gerekli izinler alınmıştır. Ayrıca çalışma grubundaki tüm öğrencilerin velilerinden yazılı onay alınmıştır. Araştırma boyunca tüm etik kurallara hassasiyetle uyulmuştur.

\section{Bulgular}

Deney ve kontrol gruplarının problem çözmeye yönelik yansıtıcı düşünme becerisi ve bilgi işlemsel düşünme beceri düzeyleri açısından öntest ve sontest puanlarının betimsel analizlerine dönük bulgular Tablo 3'te sunulmuştur. Bulgular incelendiğinde bütün faktörler ve toplam puanlar bakımından öntest ve sontest puanlarına ilişkin farklılaşmalar olduğu belirlenmiştir. 
Tablo 3

Grupların Problem Çözmeye Yönelik Yansıtıcı Düşünme Becerisi ve Bilgi İşlemsel Düşünme Beceri Düzeyleri Açısından Öntest ve Sontest Betimsel Analizleri

\begin{tabular}{|c|c|c|c|c|c|c|}
\hline & Faktörler & Uygulama & Grup & $n$ & $\bar{X}$ & $S S$ \\
\hline \multirow{24}{*}{$\begin{array}{l}\text { Problem Çözmeye } \\
\text { Yönelik Yansıtıcı } \\
\text { Düşünme Becerisi }\end{array}$} & \multirow{6}{*}{ Sorgulama } & \multirow{3}{*}{ Öntest } & Deney & 27 & 68.74 & 17.47 \\
\hline & & & Kontrol & 24 & 64.33 & 15.56 \\
\hline & & & Toplam & 51 & 66.67 & 16.58 \\
\hline & & \multirow{3}{*}{ Sontest } & Deney & 27 & 85.93 & 11.39 \\
\hline & & & Kontrol & 24 & 73.67 & 16.55 \\
\hline & & & Toplam & 51 & 80.16 & 15.22 \\
\hline & \multirow{6}{*}{ Değerlendirme } & \multirow{3}{*}{ Öntest } & Deney & 27 & 68.74 & 17.82 \\
\hline & & & Kontrol & 24 & 68.67 & 20.49 \\
\hline & & & Toplam & 51 & 68.71 & 18.93 \\
\hline & & \multirow{3}{*}{ Sontest } & Deney & 27 & 85.33 & 10.93 \\
\hline & & & Kontrol & 24 & 75.50 & 14.93 \\
\hline & & & Toplam & 51 & 80.71 & 13.76 \\
\hline & \multirow{6}{*}{ Nedenleme } & \multirow{3}{*}{ Öntest } & Deney & 27 & 65.93 & 17.43 \\
\hline & & & Kontrol & 24 & 70.63 & 17.53 \\
\hline & & & Toplam & 51 & 68.14 & 17.46 \\
\hline & & \multirow{3}{*}{ Sontest } & Deney & 27 & 82.04 & 13.39 \\
\hline & & & Kontrol & 24 & 76.88 & 16.14 \\
\hline & & & Toplam & 51 & 79.61 & 14.83 \\
\hline & \multirow{6}{*}{ Toplam } & \multirow{3}{*}{ Öntest } & Deney & 27 & 67.94 & 15.68 \\
\hline & & & Kontrol & 24 & 67.68 & 15.03 \\
\hline & & & Toplam & 51 & 67.82 & 15.23 \\
\hline & & \multirow{3}{*}{ Sontest } & Deney & 27 & 84.60 & 10.40 \\
\hline & & & Kontrol & 24 & 75.24 & 14.75 \\
\hline & & & Toplam & 51 & 80.20 & 13.36 \\
\hline \multirow{36}{*}{$\begin{array}{l}\text { Bilgi İşlemsel } \\
\text { Düşünme Beceri } \\
\text { Düzeyleri }\end{array}$} & \multirow{6}{*}{ Yaratıcılık } & & Deney & 27 & 71.48 & 18.12 \\
\hline & & Öntest & Kontrol & 24 & 81.25 & 15.69 \\
\hline & & & Toplam & 51 & 76.08 & 17.56 \\
\hline & & & Deney & 27 & 88.15 & 8.79 \\
\hline & & Sontest & Kontrol & 24 & 85.42 & 13.10 \\
\hline & & & Toplam & 51 & 86.86 & 10.99 \\
\hline & & & Deney & 27 & 65.37 & 18.24 \\
\hline & & Öntest & Kontrol & 24 & 72.29 & 14.96 \\
\hline & & & Toplam & 51 & 68.63 & 16.97 \\
\hline & Algoritmik Duşunme & & Deney & 27 & 85.00 & 9.61 \\
\hline & & Sontest & Kontrol & 24 & 76.46 & 18.02 \\
\hline & & & Toplam & 51 & 80.98 & 14.70 \\
\hline & & & Deney & 27 & 76.86 & 14.88 \\
\hline & & Öntest & Kontrol & 24 & 83.75 & 12.96 \\
\hline & İs hirlikli Öŏrenme & & Toplam & 51 & 80.10 & 14.30 \\
\hline & Iş birl1kl1 Ugrenme & & Deney & 27 & 93.33 & 7.60 \\
\hline & & Sontest & Kontrol & 24 & 88.75 & 13.77 \\
\hline & & & Toplam & 51 & 91.18 & 11.07 \\
\hline & & & Deney & 27 & 62.78 & 20.44 \\
\hline & & Öntest & Kontrol & 24 & 67.29 & 14.82 \\
\hline & Flestirel Dïsünme & & Toplam & 51 & 64.90 & 17.99 \\
\hline & Eleştırel Duşunme & & Deney & 27 & 82.96 & 10.49 \\
\hline & & Sontest & Kontrol & 24 & 75.63 & 15.76 \\
\hline & & & Toplam & 51 & 79.51 & 13.61 \\
\hline & & & Deney & 27 & 66.30 & 14.77 \\
\hline & & Öntest & Kontrol & 24 & 71.25 & 13.14 \\
\hline & Problem Cözme & & Toplam & 51 & 68.63 & 14.11 \\
\hline & Problem Çozme & & Deney & 27 & 90.74 & 8.13 \\
\hline & & Sontest & Kontrol & 24 & 88.89 & 11.98 \\
\hline & & & Toplam & 51 & 89.87 & 10.10 \\
\hline & & & Deney & 27 & 68.35 & 10.94 \\
\hline & & Öntest & Kontrol & 24 & 74.81 & 8.48 \\
\hline & Tonlam & & Toplam & 51 & 71.39 & 10.29 \\
\hline & 1оpram & & Deney & 27 & 88.28 & 6.36 \\
\hline & & Sontest & Kontrol & 24 & 83.56 & 10.87 \\
\hline & & & Toplam & 51 & 86.06 & 9.01 \\
\hline
\end{tabular}


Deney öncesine göre öğrencilerin problem çözmeye yönelik yansıtıcı düşünme becerisi puanlarında, deneysel süreç sonrasında gözlenen değişimlerin anlamlılık düzeylerine ilişkin karma ANOVA analizi sonuçları Tablo 4'de sunulmuştur.

Tablo 4

Grupların Öntest Sontest Problem Çözmeye Yönelik Yansıtıcı Düşünme Becerisi ANOVA Sonuçları

\begin{tabular}{|c|c|c|c|c|c|c|c|}
\hline Değişken & $\begin{array}{l}\text { Varyansın } \\
\text { Kaynağı }\end{array}$ & $\begin{array}{l}\text { Kareler } \\
\text { Toplamı }\end{array}$ & $s d$ & $\begin{array}{c}\text { Kareler } \\
\text { Ortalamas1 }\end{array}$ & $F$ & $p$ & $\eta^{2}$ \\
\hline \multirow{7}{*}{ Sorgulama } & Gruplar aras1 & & & & \multirow{3}{*}{5.20} & \multirow{3}{*}{.001} & \multirow{3}{*}{0.30} \\
\hline & Grup & 1764.71 & 1 & 1764.71 & & & \\
\hline & Hata & 16640.00 & 49 & 339.59 & & & \\
\hline & Gruplar içi & & & & & & \\
\hline & Zaman & 4467.59 & 1 & 4467.59 & 33.50 & .000 & 0.41 \\
\hline & Ölçüm*grup & 391.67 & 1 & 391.67 & 2.94 & .043 & 0.16 \\
\hline & Hata & 6535.70 & $\begin{array}{l}1 \\
49\end{array}$ & 133.38 & & & \\
\hline \multirow{7}{*}{ Değerlendirme } & Gruplar aras1 & & & & \multirow{3}{*}{1.56} & \multirow{3}{*}{.000} & \multirow{3}{*}{0.13} \\
\hline & Grup & 623.58 & 1 & 623.58 & & & \\
\hline & Hata & 19629.59 & 49 & 400.60 & & & \\
\hline & Gruplar içi & & & & & & \\
\hline & Zaman & 3486.33 & 1 & 3486.33 & 26.22 & .000 & 0.35 \\
\hline & Ölçüm*grup & 605.08 & 1 & 605.07 & 4.55 & .038 & 0.09 \\
\hline & Hata & 6514.93 & 49 & 132.96 & & & \\
\hline \multirow{7}{*}{ Nedenleme } & Gruplar aras1 & & & & \multirow{3}{*}{3.00} & \multirow{3}{*}{.045} & \multirow{3}{*}{0.10} \\
\hline & Grup & 1.36 & 1 & 1.36 & & & \\
\hline & Hata & 20481.48 & 49 & 417.99 & & & \\
\hline & Gruplar içi & & & & & & \\
\hline & Zaman & 3176.59 & 1 & 3176.59 & 30.29 & .000 & 0.38 \\
\hline & Ölçüm*grup & 617.77 & 1 & 617.77 & 5.89 & .119 & 0.11 \\
\hline & Hata & 5139.58 & 49 & 104.89 & & & \\
\hline \multirow{7}{*}{ Toplam } & Gruplar aras1 & & & & \multirow{3}{*}{1.90} & \multirow{3}{*}{.001} & \multirow{3}{*}{0.137} \\
\hline & Grup & 588.30 & 1 & 588.30 & & & \\
\hline & Hata & 15146.56 & 49 & 309.11 & & & \\
\hline & Gruplar içi & & & & & & \\
\hline & Zaman & 3728.59 & 1 & 3728.59 & 42.87 & .000 & 0.47 \\
\hline & Ölçüm*grup & 526.91 & 1 & 526.91 & 6.06 & .017 & 0.11 \\
\hline & Hata & 4262.20 & 49 & 86.98 & & & \\
\hline
\end{tabular}

Tablo 4'deki analiz sonuçlarına göre, ölçüm zamanı ve grup faktörlerinin etkileşim göstererek öğrencilerin problem çözmeye yönelik yansıtıcı düşünme becerisi puanlarını etkilediği görülmektedir $(F(1,49)=6.06, p<$ .05). Etki büyüklüğüne bakıldığında grup ve ölçüm ortak etkisinin, öğrencilerin toplam puanı üzerinde küçük düzeyde bir etkiye sahip olduğu görülmektedir $\left(\eta^{2}=0.11\right)$. Deney grubu öğrencilerinin öntest ve sontest puanları ile kontrol grubu öğrencilerinin puanları arasında istatistiki olarak anlamlı farklılık bulunmaktadır $(F(1,49)=$ $1.90, p<.05)$. Aynı şekilde grup ayrımı yapmaksızın ögrencilerin öntest ve sontest puanları arasında anlamlı farklılık olduğu görülmektedir $(F(1,49)=42.87, p<.05)$. Etki büyüklüğüne bakıldığında ise grup ayrımı yapılmaksızın verilen eğitimlerin öğrencilerin problem çözmeye yönelik yansıtıcı düşünme becerisi toplam puanlarının üzerinde orta düzeyde bir etkiye sahip olduğu görülmektedir $\left(\eta^{2}=0.47\right)$

Faktörler bakımından incelendiğinde sadece nedenleme faktöründe, ölçüm zamanı ve grup faktörlerinin etkileşim göstermesi bakımından anlamlı bir farklılık olmadığ dikkati çekmektedir $(F(1,49)=5.89, p>.05)$. Bununla birlikte, gruplar arası ve grup içi faktörlerin etkilerinin sonuçlarına tek tek bakıldığında, zamana göre öntest sontest puanları arasında istatistiksel olarak anlamlı farklıklar olduğu görülmektedir. Etki büyükleri incelendiğinde ise orta ve yüksek düzeyde değişmekte olduğu dikkati çekmektedir. Bu sonuçlara göre oyunlaştırılmış eğitsel robot etkinliklerinin, öğrencilerin problem çözmeye yönelik yansıtıcı düşünme becerisi becerilerine kontrol grubunda uygulanan Scratch eğitimi etkinliklerine göre anlamlı düzeyde daha fazla katk1 sağladı̆̆ söylenebilir.

Deney öncesine göre öğrencilerin bilgi işlemsel düşünme beceri düzeyleri puanlarında, deneysel süreç sonrasında gözlenen değişimlerin anlamlılık düzeylerine ilişkin karma ANOVA analizi sonuçları Tablo 5'de özetlenmiştir. 
Tablo 5

Grupların Öntest Sontest Bilgi İslemsel Düşünme Beceri Düzeyleri ANOVA Sonuçları

\begin{tabular}{|c|c|c|c|c|c|c|c|}
\hline Değişken & Varyansın kaynağı & $\begin{array}{c}\text { Kareler } \\
\text { Toplamı }\end{array}$ & $s d$ & $\begin{array}{c}\text { Kareler } \\
\text { Ortalamas1 }\end{array}$ & $F$ & $p$ & $\eta^{2}$ \\
\hline \multirow{7}{*}{ Yaratıcilık } & Gruplar arası & & & & & & \\
\hline & Grup & 314.60 & 1 & 314.60 & 0.95 & .000 & 0.19 \\
\hline & Hata & 16239.82 & 49 & 331.43 & & & \\
\hline & Gruplar içi & & & & & & \\
\hline & Zaman & 2757.35 & 1 & 2757.35 & 34.50 & .000 & 0.41 \\
\hline & Ölçüm*grup & 992.65 & 1 & 992.65 & 12.42 & .001 & 0.20 \\
\hline & Hata & 3916.67 & 49 & 79.93 & & & \\
\hline \multirow{7}{*}{ Algoritmik Düşünme } & Gruplar aras1 & & & & & & \\
\hline & Grup & 16.68 & 1 & 16.68 & 0.042 & .000 & 0.11 \\
\hline & Hata & 19304.40 & 49 & 393.97 & & & \\
\hline & Gruplar içi & & & & & & \\
\hline & Zaman & 3597.44 & 1 & 3597.44 & 40.39 & .000 & 0.45 \\
\hline & Ölçüm*grup & 1519.01 & 1 & 1519.01 & 17.05 & .000 & 0.26 \\
\hline & Hata & 4364.82 & 49 & 89.08 & & & \\
\hline \multirow{7}{*}{ İş birlikli Öğrenme } & Gruplar aras1 & & & & & & \\
\hline & Grup & 34.04 & 1 & 34.04 & 0.14 & .000 & 0.33 \\
\hline & Hata & 11712.04 & 49 & 239.02 & & & \\
\hline & Gruplar içi & & & & & & \\
\hline & Zaman & 2931.59 & 1 & 2931.59 & 38.10 & .000 & 0.44 \\
\hline & Ölçüm*grup & 837.47 & 1 & 837.47 & 10.88 & .002 & 0.18 \\
\hline & Hata & 3770.37 & 49 & 76.95 & & & \\
\hline \multirow{7}{*}{ Eleştirel Düşünme } & Gruplar arası & & & & & & \\
\hline & Grup & 50.67 & 1 & 50.67 & 0.13 & .001 & 0.12 \\
\hline & Hata & 18915.51 & 49 & 386.03 & & & \\
\hline & Gruplar içi & & & & & & \\
\hline & Zaman & 5166.89 & 1 & 5166.89 & 45.38 & .000 & 0.48 \\
\hline & Ölçüm*grup & 892.38 & 1 & 892.38 & 7.84 & .007 & 0.14 \\
\hline & Hata & 5578.70 & 49 & 113.85 & & & \\
\hline \multirow{7}{*}{ Problem Çözme } & Gruplar arası & & & & & & \\
\hline & Grup & 61.13 & 1 & 61.13 & 1.31 & .048 & 0.11 \\
\hline & Hata & 9575.69 & 49 & 195.42 & & & \\
\hline & Gruplar içi & & & & & & \\
\hline & Zaman & 11251.10 & 1 & 11251.10 & 108.22 & .000 & 0.69 \\
\hline & Ölçüm*grup & 294.24 & 1 & 294.24 & 2.83 & .099 & 0.06 \\
\hline & Hata & 5094.21 & 49 & 103.96 & & & \\
\hline \multirow{7}{*}{ Toplam } & Gruplar arası & & & & & & \\
\hline & Grup & 19.20 & 1 & 19.20 & 2.13 & .000 & 0.11 \\
\hline & Hata & 7085.78 & 49 & 144.69 & & & \\
\hline & Gruplar içi & & & & & & \\
\hline & Zaman & 5226.53 & 1 & 5226.53 & 176.50 & .000 & 0.78 \\
\hline & Ölçüm*grup & 794.45 & 1 & 794.45 & 26.83 & .000 & 0.35 \\
\hline & Hata & 1451.02 & 49 & 29.61 & & & \\
\hline
\end{tabular}

Tablo 5'te görüldüğü gibi, deney ve kontrol gruplarının deney öncesi ve sonrası toplam puanları arasında anlamlı bir farklılık görülmektedir $(F(1,49)=26.83, p<.05)$. Bu durum, ölçüm zamanı ve grup faktörlerinin etkileşim göstererek öğrencilerin bilgi işlemsel düşünme beceri düzeyleri puanlarını etkilediğini göstermektedir. Bulgular, grup ve ölçüm ortak etkisinin öğrencilerin toplam puanı üzerinde orta düzeyde bir etki büyüklüğüne sahip olduğunu göstermiştir $\left(\eta^{2}=.35\right)$. Analiz sonucunda görülen bir diğer bulgu ise grup ayrımı yapmaksızın öğrencilerin öntest sontest puanları arasında anlamlı bir fark olmasıdır $(F(1,49)=176.50, p<.05)$. Etki büyüklüğü, grup ayrımı yapılmaksızın verilen eğitimlerin öğrencilerin bilgi işlemsel düşünme beceri düzeyleri toplam puanları üzerinde büyük bir etkiye sahip olduğunu göstermektedir $\left(\eta^{2}=.78\right)$.

Öğrencilerin bilgi işlemsel düşünme beceri düzeyleri puanları alt faktörler açısından incelendiğinde ise ölçüm zamanı ve grup faktörlerinin etkileşim göstermesi bakımından problem çözme faktörü dışında $(F(1,49)=2.83$, $p>.05)$, diğer boyutlarda anlamlı farklılıklar olduğu görülmektedir. Bununla birlikte, gruplar arası ve grup içi faktörlerin etkilerinin sonuçlarına tek tek bakıldığında, zamana göre öntest sontest puanları arasında istatistiksel olarak anlamlı farklıklar olduğu görülmektedir. Etki büyükleri incelendiğinde ise genelde orta ve yüksek düzeyde değişmekte olduğu dikkati çekmektedir. Elde edilen bulgulara göre, oyunlaştırılmış eğitsel robot etkinliklerinin, öğrencilerin bilgi işlemsel düşünme beceri düzeylerine anlamlı düzeyde daha fazla katkı sağladığı söylenebilir. 


\section{Sonuç ve Tartışma}

$\mathrm{Bu}$ araştırmada oyunlaştırılmış eğitsel robot etkinliklerinin, ortaokul öğrencilerinin problem çözmeye yönelik yansıtıcı düşünme ve bilgi işlemsel düşünme beceri düzeylerine etkisi ele alınmıştır. Araştırmada elde edilen bulgulara göre, oyunlaştırılmış eğitsel robotlar ile yapılan kodlama dersleri, öğrencilerin problem çözmeye yönelik yansıtıcı düşünme beceri düzeylerine anlamlı düzeyde katkı sağlamaktadır. Faktörler arasında en yüksek farklılaşma sorgulama faktörü düzeyinde, en düşük farklılaşma nedenleme faktöründe görülmüştür. Alanyazında bu sonucu destekler nitelikte araştırmalara rastlamak mümkündür. Örneğin Kıran (2018) tarafindan yapılan bir çalışmada, 12-13 yaş arası üstün yetenekli öğrencilerle yapılan proje tabanlı temel robot kodlama eğitiminin, öğrencilerin yansıtıcı düşünme ve problem çözmeye dair becerilerine katkı sağladığı hatta aradan belirli bir zaman geçmesine rağmen öğrencilerin hâlen çalışma ve projelere devam ettikleri belirlenmiştir. Pace Üniversitesinde verilen Legolarl Kullanarak Problem Çözme Dersi kapsamında üniversite öğrencilerinin ortaokul öğrencilerine verdikleri eğitsel robotlarla kodlama eğitiminde öğrencilerin problem çözme becerilerinde artış olduğu tespit edilmiştir (Mosley ve Kline, 2006). Yine Amerika'da Harp Akademilerinde verilen Bilişim Teknolojileri derslerinde, eğitsel robotlar problem çözme becerilerinin öğretilmesi amacı ile kullanılmakta ve olumlu dönütler alınmaktadır (Flowers ve Gossett, 2002). Yükseltürk, Altık ve Üçgül (2016) tarafindan yürütülen Tübitak'ın desteklediği Kendi Oyunumu Programlıyorum isimli yaz kampı etkinliğinde ise kodlama eğitimi verilen 6. ve 7. sınıf öğrencilerinin problem çözme becerilerinde olumlu bir artış olduğu gözlenmiştir. Son zamanlarda özellikle veliler, çocuklarının sorgulama, problem çözme, analiz ve sentez yapabilme, değerlendirme, yaratıcı düşünme, eleştirel düşünme, iş birlikli çalışma gibi becerilerinin artmasını istemektedir (Akpınar ve Altun, 2014). Tüm bunları eğlenceli bir şekilde artırabilmenin en kolay yolu, kodlama eğitimidir (Fesakis ve Serafeim, 2009). Kodlama eğitimini veya herhangi bir eğitimi, eğlenceli ve daha ilgi çekici hâle getirmenin yolu da eğitsel robotları ve oyunlaştırma unsurlarını kullanarak verilen eğitimdir (Yıldırım ve Demir, 2014). Küçük ve Şişman (2016) yaptıkları çalışmada, eğitsel robotlar ile verilen eğitimin, öğrencilerin dikkat ve motivasyonlarını yüksek düzeyde tutmayı sağlayarak öğrenmeyi kolaylaştırdığı sonucuna ulaşmışlardır. Ayrıca çocukların elle tutulur ürünler ortaya koyabilmeleri ve bunların hareket ediyor olması, ilgilerinin daha da artmasını ve eğlenerek öğrenmelerini sağladığı belirlenmiştir. Sarı ve Altun'un (2016) yaptıkları çalışmada ulaştıkları sonuca göre, oyunlaştırma ögeleri ile işlenen bilgisayar dersleri öğrenciler açısından daha motive edici ve ilgi çekici bulunmuş, aralarındaki rekabet ortamını artırdığı için öğrencilerin derse katılımları üzerinde de olumlu bir etki yarattığı vurgulanmıştır. Dehmenoğlu (2015) bu durumu destekler biçimde kodlama eğitiminde oyunlaştırmanın başarıyı arttırdığını belirtmekte ve oyunlaştırma unsurlarını kullanmanın etkili olacağını önermektedir. Bu çalışmada da kullanılmış olan rozet verme, rol paylaşımı, hikâyeleştirme, iş birliği, liderlik tablosu gibi oyunlaştırma unsurlarının, öğrencilerin süreçten daha çok zevk almalarını ve mutlu olmalarını sağladığı vurgulanmıştır.

Oyunlaştırılmış eğitsel robotlar ile yapılan kodlama dersleri, öğrencilerin bilgi işlemsel düşünme beceri düzeylerine anlamlı düzeyde daha fazla katkı sağlamaktadır. Faktörler açısından incelendiğinde ise algoritmik düşünme, yaratıcılık, iş birlikli öğrenme, eleştirel düşünme ve problem çözme faktörleri açısından anlamlı bir farklılaşmanın olduğu belirlenmiştir. Alanyazında bu sonucu destekler nitelikte araştırmalara rastlamak mümkündür. Strawhacker ve Bers (2015), öğrencilerin Lego WEDO eğitsel robotları kullanmalarını sağladıkları çalışmalarında, söz konusu bireylerin özellikle bilgi işlemsel düşünme becerilerinde artış olduğunu belirtmişlerdir. Eğitsel robotlar ile etkinlik çalışması yaparak öğrenen öğrenciler, bilgi işlemsel düşünmenin bu alt boyutlarını kullanarak kendilerini geliştirebilmektedirler (Gülbahar, 2018). Bu çalışmada kullanılan Bilgi Işslemsel Düşünme Beceri Düzeyleri Ölçeğinin de alt faktörlerinden biri olan öğrencilerin problem çözme becerilerinin kodlama ve robotik üzerine çalışma yapma durumuna göre değişip değişmediğini araştıran Şanal ve Erdem (2017), kodlama yapan öğrencilerin özellikle teknik alandaki problemleri çözme süreçlerinin kodlama yapmayan öğrencilere göre daha iyi düzeyde olduğunu saptamışlardır. Begosso ve Da Silva (2013), 11-13 yaşları arasındaki öğrencilerle üç ay süren Scratch eğitiminden sonra öğrencilerin daha önce zorlandıkları algoritmik düşünme ve programlama becerilerini arttırdıklarını ayrıca mantıksal-matematiksel düşünme ve problem çözme becerilerinde de artış olduğunu ortaya koymuşlardır. Korkmaz (2016) tarafindan Lego MindStorms EV3 robotları ile yapılan deneysel bir çalışmada, eğitsel robot kullanarak konuyu öğrenen öğrencilerin akademik başarıları, mantıksal-matematiksel düşünme becerileri ve problem çözme becerileri, geleneksel yöntemle kodlama öğrenen öğrencilere göre anlamlı düzeyde farklı bulunmuştur.

Ayrıca bu çalışmada kontrol grubunda da yürütülen öğretim uygulamasının, öğrencilerin problem çözmeye yönelik yansıtıcı düşünme becerileri üzerinde sınırlı bir katkısının, bilgi işlemsel düşünme beceri düzeylerine ise anlamlı bir katkısının olduğu görülmektedir. Bunun sebebinin ise oyunlaştırma ya da oyunlaştırılmış eğitsel robotlar kullanılmasa bile öğrencilerin Bilişim Teknolojileri ve Yazılım dersini ve blok tabanlı kodlamayı sevmeleri ve ilgi duymaları olarak gösterilebilir. Çünkü blok tabanlı kodlama ortamları, metin tabanlı kodlama ortamlarına göre çok daha kolay ve anlaşılır bir arayüz sunmaktadır. (Aytekin, Sönmez Çakır, Yücel ve Kulaözü, 2018). Araştırma kapsamında elde edilen sonuçlara göre şu önerilerde bulunulabilir: 
1. Öğrencilerin bilgi işlemsel düşünme ve problem çözme becerilerini geliştirmek amacıyla oyunlaştırılmış eğitsel robot uygulamalarından yararlanılabilir.

2. Problem çözme açısından nedenleme, bilgi işlemsel düşünme açısından ise eleştirel düşünme ve problem çözme faktörlerinde yeterince gelişme sağlanamadı̆̆ı göz önünde bulundurularak oyunlaştırılmış eğitsel robot uygulamaları tasarlanırken bu faktörlerle ifade edilen becerilere dönük daha fazla etkinliğe yer verilmesi önemlidir.

3. $\mathrm{Bu}$ çalışma kapsamında deneysel uygulamalar gerçekleştirilirken sınıf yöntemi, grupların oluşturulması, gruplara kılavuzluk yapılması gibi konularda öğrenci sayısının fazla olmasından kaynaklı sorunlarla karşılaşılmıştır. Bu çerçevede oyunlaştırılmış eğitsel robotlara dönük uygulamalar planlanırken, sınıf mevcudunun göz önünde bulundurulması ve kalabalık sınıflarda yaşanabilecek aksaklıklara dönük düzenlemeler yapılması gerekmektedir.

4. Bu çalışma kapsamında yeterince eğitsel robot seti olmadığından oyunlaştırma etkinlikleri gruplar hâlinde yapılmış, yöntemin bireysel şekilde uygulandığında etkililiği ölçülememiştir. Bu konuda gelecekte yapılacak olan çalışmalarda bireysel etkinliklerin etkililiğinin de belirlenmesi amacıyla, uygulamaların bireysel olarak yapılması düşünülebilir. 


\section{Kaynakça}

Akpınar, Y. ve Altun, A. (2014). Bilgi toplumu okullarında programlama eğitimi gereksinimi. İlköğretim Online, 13(1), 1-4.

Arkün Kocadere, S. ve Samur, Y. (2016). Oyundan oyunlaştırmaya. A. İşman, F. Odabaşı, ve B. Akkoyunlu (Ed.), Eğitim Teknolojileri Okumaları içinde (ss. 397-414). Ankara: Pegem Yayınevi.

Armoni, M. (2012). Teaching CS in kindergarten: How early can the pipeline begin? Acm Inroads, 3(4), 18-19.

Aytekin, A., Sönmez Çakır, F., Yücel, Y. B. ve Kulaözü, İ. (2018). Geleceğe yön veren kodlama bilimi ve kodlama öğrenmede kullanılabilecek bazı yöntemler. Avrasya Sosyal ve Ekonomi Araştırmaları Dergisi, $5(5), 24-41$.

Barr, D., Harrison, J., \& Conery, L. (2011). Computational thinking: A digital age skill for everyone. Learning \& Leading with Technology, 38(6), 20-23.

Barr, V., \& Stephenson, C. (2011). Bringing computational thinking to K-12: What is involved and what is the role of the computer science education community? Acm Inroads, 2(1), 48-54.

Battle For Kids (2019). Partnership for 21st Century Skills. Retrieved from http://www.battelleforkids.org/networks/p21

Baz, F. Ç. (2018). Çocuklar için kodlama yazılımları üzerine karşıllaştırmalı bir inceleme. Curr Res Educ, 4(1), 36-47.

Begosso, L. C., \& da Silva, P. R. (2013). Teaching computer programming: A practical review. IEEE Frontiers in Education Conference (FIE), Proceedings Book (pp. 508-510), Oklahoma City, OK, USA: IEEE doi:10.1109/FIE.2013.6684875

Bozkurt, A. ve Genç Kumtepe, E. (2014, Şubat). Oyunlaştırma, oyun felsefesi ve eğitim: Gamification. Akademik Bilişim Konferans1, Mersin. http://ab.org.tr/ab14/bildiri/233.pdf adresinden elde edildi.

Büyüköztürk, Ş. (2013). Sosyal bilimler için veri analizi el kitabı (18. baskı). Ankara: PegemA Yayıncılık.

Çankaya, S., Durak, G. ve Yünkül, E. (2017). Robotlarla programlama eğitimi: öğrencilerin deneyimlerinin ve görüşlerinin incelenmesi. Turkish Online Journal of Qualitative Inquiry, 8(4), 428-445. doi:10.17569/tojqi.343218

Çetin, E. (2012). Bilgisayar programlama eğitiminin çocukların problem çözme becerileri üzerine etkisi. (Yayımlanmamış yüksek lisans tezi). Gazi Üniversitesi, Ankara.

Dehmenoğlu, C. (2015). Programlama temelleri dersine yönelik mobil öğrenme aracının geliştirilmesi. (Yayımlanmamış yüksek lisans tezi). Bahçeşehir Üniversitesi, İstanbul.

Demir, Ö. ve Seferoğlu, S. S. (2017, Ekim). İşbirlikli problem çözmenin kodlama öğretimine yansıması olarak eşli kodlamanın incelenmesi. 5. Uluslararası Öğretim Teknolojileri ve Öğretmen Eğitimi Sempozyumu, İzmir.http://yunus.hacettepe.edu.tr/ sadi/yayin/ITTES2017_Demir-Seferoglu_Esli-Kodlama.pdf adresinden elde edildi.

Deterding, S., Sicart, M., Nacke, L., O'Hara, K., \& Dixon, D. (2011). Gamification. using game-design elements in non-gaming contexts. In D. Tan, B. Begole (Ed.), CHI'll Extended Abstracts on Human Factors in Computing Systems. (pp. 2425-2428), Vancouver BC Canada: Acm, doi:10.1145/1979742.1979575

Erdem, E. (2018). Blok tabanlı ortamlarda programlama öğretimi sürecinde farklı öğretim stratejilerinin çeşitli değişkenler açısından incelenmesi. (Yayımlanmamış yüksek lisans tezi). Başkent Üniversitesi, Ankara.

European Commission (2018). Coding-the 21st century skill. European Commission. Retrieved from https://ec.europa.eu/digital-single-market/coding-21st-century-skill

Fesakis, G., \& Serafeim, K. (2009). Influence of the familiarization with scratch on future teachers' opinions and attitudes about programming and ICT in education. Acm SIGCSE Bulletin, 41(3), 258-262. doi: $10.1145 / 1595496.1562957$ 
Flowers, T. R., \& Gossett, K. A. (2002). Teaching problem solving, computing, and information technology with robots. Journal of Computing Sciences in Colleges, 17(6), 45-55.

Gökkaya, Z. (2014). Yetişkin eğitiminde yeni bir yaklaşım: oyunlaştırma. HAYEF: Journal of Education, 1(1), 71-84.

Gülbahar, Y. (2018). Bilgi işlemsel düşünmeden programlamaya (3. baskı). Ankara: Pegem Yayıncılık.

International Society for Technology in Education [ISTE]. (2019). Computational thinking competencies. Retrieved from https://www.iste.org/standards/computational-thinking

Kalelioğlu, F. ve Gülbahar, Y. (2014). The effects of teaching programming via scratch on problem solving skills: A discussion from learners' perspective. Informatics in Education, 13(1), 33-50.

Kasalak, İ. (2017). Robotik kodlama etkinliklerinin ortaokul öğrencilerinin kodlamaya ilişkin özyeterlik algılarına etkisi ve etkinliklere ilişkin ögrenci yaşantıları. (Yayımlanmamış yüksek lisans tezi). Hacettepe Üniversitesi, Ankara.

Kıran, B. (2018). Üstün yetenekli ortaokul öğrencilerinin proje tabanlı temel robotik ĕgitim süreçlerindeki yaratıcı, yansıtıcı düşünme ve problem çözme becerilerine ilişkin davranışlarının ve görüşlerinin incelenmesi. (Yayımlanmamış yüksek lisans tezi). Başkent Üniversitesi, Ankara.

Kızılkaya, G. ve Aşkar, P. (2009). Problem çözmeye yönelik yansıtıcı düşünme becerisi ölçeğinin geliştirilmesi. Eğitim ve Bilim, 34(154), 82-92.

Korkmaz, Ö. (2016). The effect of scratch-and lego mindstorms Ev3-Based programming activities on academic achievement, problem-solving skills and logical-mathematical thinking skills of students. MOJES: Malaysian Online Journal of Educational Sciences, 4(3), 73-88.

Korkmaz, Ö., Çakır, R. ve Özden, M. Y. (2015). Bilgisayarca düşünme beceri düzeyleri ölçeğinin (BDBD) ortaokul düzeyine uyarlanması. Gazi Ĕgitim Bilimleri Dergisi, 1(2), 143-162.

Korkmaz, Ö., Çakır, R., Özden, M. Y., Oluk, A. ve Sarığlu, S. (2015). Bireylerin bilgisayarca düşünme becerilerinin farklı değişkenler açısından incelenmesi. Ondokuz Mayls Üniversitesi Ĕ̈itim Fakültesi Dergisi, 34(2), 68-87.

Küçük, S. ve Şişman, B. (2016). Birebir Robotik Öğretiminde Öğreticilerin Deneyimleri. Illköğretim Online, 16(1), 312-325. doi:10.17051/io.2017.12092

Lee E., Kafai Y. B., Vasudevan V., \& Davis R. L. (2014). Playing in the arcade: Designing tangible interfaces with MaKey MaKey for scratch games. In Nijholt A. (ed.), Playful user interfaces. (pp. 277-292). Springer, Singapore.

McKillup, S. (2012). Statistics explained: An introductory guide for life scientists (2nd ed.). United States: Cambridge University Press.

Mosley, P., \& Kline, R. (2006). Engaging students: A framework using lego robotics to teach problem solving. Information Technology, Learning \& Performance Journal, 24(1), 39-45.

Numanoğlu, M. ve Keser, H. (2017). Programlama öğretiminde robot kullanımı - Mbot örneği. Bartın Üniversitesi Eğitim Fakültesi Dergisi, 6(2), 497-515. doi:10.14686/buefad.306198

Oluk, A. ve Korkmaz, Ö. (2018). Bilişim teknolojileri öğretmenlerinin eğitsel robotların kullanımına yönelik görüşleri. Pegem Atıf Índeksi, 0, 215-224. doi:10.14527/3381

Özden, M. Y. (2015). Computational thinking. http://myozden.blogspot.com.tr/ 2015/06/computational-thinkingbilgisayarca.html adresinden elde edildi.

Resnick, M., \& Silverman, B. (2005). Some reflections on designing construction kits for kids. In M. Eisenberg, A. Elsenberg (Ed.), Proceedings of the 2005 conference on interaction design and children.(pp. 117-122). Boulder, Colorado, USA: Acm. doi:10.1145/1109540.1109556 
Sarı, A. ve Altun, T. (2016). Oyunlaştırma yöntemi ile işlenen bilgisayar derslerinin etkililiğine yönelik öğrenci görüşlerinin incelenmesi. Türk Bilgisayar ve Matematik Eğitimi Dergisi, 7(3), 553-577.

Sezgin, S., Bozkurt, A., Yılmaz, E. A. ve van der Linden, N. (2018). Oyunlaştırma, eğitim ve kuramsal yaklaşımlar: Öğrenme süreçlerinde motivasyon, adanmışlık ve sürdürebilirlik. Mehmet Akif Ersoy Üniversitesi Eğitim Fakültesi Dergisi, 45, 169-189.

Shapiro, S. S., \& Wilk, M. B. (1965). An analysis of variance test for normality (complete samples). Biometrika, 52(3/4), 591-611.

Strawhacker, A., \& Bers, M. U. (2015). I want my robot to look for food: Comparing kindergartner's programming comprehension using tangible, graphic, and hybrid user interfaces. International Journal of Technology and Design Education, 25(3), 293-320.

Şanal, S. Ö. ve Erdem, M. (2017, Mayıs). Kodlama ve robotik çalışmalarını problem çözme süreçlerine etkisi: Sesli düşünme protokol analizi. Sözlü Bildiri. 11. Uluslararası Bilgisayar ve Öğretim Teknolojileri Sempozyumu, Malatya.

Üçgül, M. (2017). Eğitsel robotlar ve bilgi işlemsel düşünme. Y. Gülbahar (Ed.), Bilgi işlemsel düşünmeden programlamaya içinde (ss. 295-314). Ankara: Pegem Yayınları.

Werbach, K., \& Hunter, D. (2012). For the win: How game thinking can revolutionize your business. Wharton Digital Press.

Yıldırım, İ., ve Demir, S. (2014). Oyunlaştırma ve eğitim. International Journal of Human Sciences, 11(1), 655670. doi:10.14687/ijhs.v11i1.2765

Yıldız Durak, H., Karaoğlan Yılmaz, F. G., Yılmaz, R. ve Seferoğlu, S. (2017). Erken yaşta programlama eğitimi: Araştırmalardaki güncel eğilimlerle ilgili bir inceleme. A. İşman, F. Odabaşı, ve B. Akkoyunlu (Ed.), Ĕ̌itim Teknolojileri Okumaları içinde (ss. 205-236). Ankara: Pegem Yayınevi.

Yılmaz, E. A. (2015). Oyunlaştırma (4. bask1). İstanbul: Abaküs Yayınları.

Yükseltürk, E., Altık, S. ve Üçgül, M. (2016, Ekim). Oyun programlamanın ilköğretim öğrencilerinin problem çözme becerilerine etkileri: Bir yaz kampı deneyimleri. Sözlü Bildiri. 4th International Instructional Technologies \& Teacher Education Symposium, Elazı̆ 
Ek A

Oyunlaştırılmış Eğitsel Robotlar İle Blok Tabanlı Programlama Öğretimi

Deney Grubu Etkinlik Planı - 1. Hafta

Ders: Bilişim Teknolojileri ve Yazılım

Süre: $40+40 \mathrm{dk}$

Etkinlik Adı: Kesilince Bağıran Meyve ve Sebzeler

\begin{tabular}{|c|c|c|c|}
\hline Öğrenme Alanı: & $\begin{array}{l}\text { Blok Tabanlı } \\
\text { Programlama }\end{array}$ & Alt öğrenme Alanı: & $\begin{array}{l}\text { - Karakter düzenleme (ses ekleme } \\
\text { vb) } \\
\text { - Sahne düzenleme } \\
\text { - Alg1lama bloklar1 }\end{array}$ \\
\hline
\end{tabular}

- Algoritma ve strateji geliştirme

- Algilama blokları

Kazanımlar:

BíT kaynakları ve
materyaller:

Giriş / Problem

Durumu:

Uygulama Stratejileri:
Oyunun Kuralları (Oyunlaştırmanın Dinamikleri MekanikleriBileşenleri):

\section{Oyun İçin Ön} Hazırlık:

Etkinlik Uygulama Şekli:
- Öğrenciler algoritma ve yazılım kavramlarını açıklayabilir ve örnekler verebilir.

- Scratch programının özelliklerini ve bu program ile yapabileceklerini sıralar.

- Basit bazı komutları öğrenir.

- Öğrenciler istedikleri karakterleri ve sahneleri projelerine nasıl ekleyeceklerini öğrenir.

- Projelerine nasil ses ekleyebileceklerini ve karakterlerinin renklerini nasil değiştireceklerini öğrenirler.

- Scratch Program1

- Etkileşimli tahta

- Tuşyarat veya tuşyap eğitsel robot kiti

- Birkaç çeşit sebze, meyve (ya da oyun hamuru)

- Metal bir yemek bıçağ

Eğlenceli bir oyun tasarımı yapmak istiyoruz. Amacımız meyve ve sebzeleri (gerçekleri yoksa oyun hamurundan da yapabiliriz) bıçağımız ile kesmeye çalıştığımızda ses çıkarıp, çığlık atmaları

- Öncelikle öğrencilerin problemin çözümüne ilişkin bir algoritma ve strateji belirlemeleri beklenir.

- Scratch programında kukla nasıl eklenir ve kukla kılıkları nasıl düzenlenir konusu anlatilir.

- Kuklaya ses ekleme konusu anlatılır.

- Algılama bloklarından bahsedilerek örnek yapılır ( bıçağın meyveye dokunup dokunmadığını anlamaları için)

- Oyun ekranının daha güzel görünmesi için sahne tasarımının nasıl yapılacağı anlatılır. Makey Makey, Tuşyarat veya Tuşyap eğitsel robot kitinin kullanımında dikkat edilmesi gereken kurallardan bahsedilerek, gösterip yaptırma yöntemi ile oyun sınıfta öğretmen tarafindan bir kez oynanır.

- Oyunun kodlamasını ilk bitiren ekip, (Makey Makey, Tuşyarat, Tuşyap kitini kullanarak) oyunu oynayacak ve Scratch Rozeti kazanacaklardır (Rekabet)

- Bitiren ilk 3 ekibin oyunu oynarken fotoğrafları çekilecek ve okulun Bilişim Teknolojileri panosunda 1 hafta süre ile sergilenecektir (Ödül)

- Etkinliklerin devam ettiği 5 hafta boyunca en çok Scratch Rozeti kazanan grup Ögretmen Özel Ödülü kazanacak ve öğretmen özel asistanlık görevine getirileceklerdir. (Liderlik, Rol Paylaşımı)

- Öğrencilerden önceden evden birkaç çeşit sebze- meyve getirmeleri istenir. (Oyun hamuru da getirilip, sebze meyve şekilleri verilebilir)

- Etkinlikler proje tabanlı grup çalışması şeklinde yapılacaktır.

- Kursta bulunan 27 öğrenci 3'er kişilik gruplara bölünecek ve çalışmalarını grup olarak sunacaklardır. 